present, he seems to lis doing well, and there lons been practienly no lealatge of bile; his stomach is irritable, nud he hus dillieulty in rotuining food. As it is now seven dnys since, and he has no sign of peritomitis, I think he will pull through.

I would like to call attention to the fact that the adhesions found at the time of the second operation inevented 1)r. Brewer from using the technic already deseribed, and I feel that failure to make the duodenal gutter grently handicals the suceess of the work. Further than this, the first tube inserted was never foumd by $x$-riny, nor in the stonls, and so the length of time the tube was in situ can hardly be guesserl. $\Lambda$ few days linter Dr. Brewer wrote me as follows:

I am sorry to be obliged to tell you that my patient died as the result of his second operation. Jis condition was pretty land at the time from eholemin, and the wound oozed for nbout ten days, which grently wenkened him. At the ond of this time. the hemorrhage censed and he began to take nourishment, lust the bile nover flowed freely into the intestine. Why l cannot imagine, becunse the duet was compled up to the duodemum by a large tube through which the bile flowed laring the operation. 'lhe temperature kept almost to the normal, and there was no peritonitis. No antopsy wins permitted.

The most striking thing to me, in the convalesence after this work experimentally, and as borne out by lorofessor Brewer's experience in both operations, is that there is no biliary lenkange and no peritonitis. One would supmose that there would be lenkage at the point "t which the tube enters the duodenum, at which place there must be some peristaltic back pressure. Such is not the case, however.

It is also curious that it is diflicult to keep the tube in situ for anc length of time without consiclernble enre in anchoring it firmly with umabsombable sutures.

The one point in this work about which there is some skepticism is whether or not the fistula will eventually ciose. If it is ultimately proved thant in the human heing a bilinry sinus will not remain patent, a tube with flanges may be inserted, and thus loeld in siln permanently.

I have cndleavored to present all nngles of this work, so that it may be analyzed. It must stand or fall on its merits. I would esteem. it a favor, if the men who have hat cass's of the nature this method is intended fon will criticize its shorteomings.

28 West Milllin Strect.

\section{BERIBERI CAUSED BY FINE WIIITE FLOUR}

\section{JOIIN M, JI'TlTA, M.l).}

ST. ANTHONY, NLWHOL:NDTAND

The etiology of beriberi in rice-eating countries has hul a grent deal of light thrown on it recently. One frequently sees reports in the medical and lay press of cases arising on shipboard or in different parts of the world where the cating of polished rice cunnot be the canse; reports from medical men proving that rice has mothing to do with it; reports of measures being taken by health oflicers on the assumption that it is an infectious disense. In spite of the linowledge gained, the disense seems not to be generally understood in such a way that rational mensures are instituted when it aprenis, or that preventive measures are aclopted where it is likely to occur. There is no doubt about the canse in the minds of the mon who are working in the ricerating communities, but they do not sie the cases arising from other diets (perhaps the snme cause). While the work of these men is very definite and their results splendid, they have not been rightly interpreted by men who see beriberi arising from other diets. 'The reason of this is that the connection between cause and effect is not so plain. Contributing causes and intermittent conditions clond the pieture. It is in the hope that this difficulty mar be removed and that better prophylaxis and treatment may be instituted, even where beriberi is not so prevalent or severe as in castern lani!s, that I an writing some observations made clinically during five vears in a whent-enting country where beriberi is fairly common, that is, Newfoundland and Taborador.

There are pople in this country who, especially at certain times of the year - mid-winter and spring, and in summer on their fishing veseels - come down to a riet of bread and tea. In other words, sulstitute whent for rier, and we have the exnet enditions which are seen in the enst. The conclitions are eompliented by vicious physical states, arising from other causes, such as actual starvation, exposure, hardship, unlygienic eonditions (this last to be insisted on and emphasized without going into details), so that malnutrition, physinal exhnustion, scurvy and various minor and major pathologie metabolic processes are to be considered. Yet these ean all be thrown out, and case after case demonstrated in which there is affection of the nerves, and almost invariably it is found that such patients have been or are, to all intents and purposes, on a diet of overmilled wheat, by which I mean ordinary fine white flour.

A great many people liere live from hand to mouth, bcing always on the verge of poverty. There are many who are well satisfied if they have enough flour, tea and molasses to see them through the winter. Agriculture is so discouraging that many never have a vegetable. (iame, decr, birds, rabbits, senls are scarce and getting s(areer. Berries, though abumdant in the fall, are hard to gather. Fish is worth more to sell than to eat for with it flour, which is the elhenpest food, is bought. Nithough there are times of the year when such people get all of these, there are times when they get none of them and those are the times when the physician begins to hear various complaints. These complaints are in many conses vogue, in some definite. Such for instance are niglit-blindness, retention of urine, numbness or cold feelings, tingling in the logs or arms, or across the ablomen or mouth, feelings of water running up and down under the skin, ete. These are the paresthesias, the functional nervous troubles which are the prodromal stiage of beriberi. They are very common. Tet the vessel get home or the spring come, the ice brenk up, navigation open and a more varied diet be taken, and they disappear. But let an added burden be thrown on the economy, whether it be pregnancy, a wetting and chill or a cold; add the squalor and discomfort, dirt and bal air of one of the air-tight overheated cottages the natives live in, increased by the neglect coused by their own undermined health, then you will see the condition alvancing sometimes very rapilly to the later stages of sensory and motor parnlysis, with affection of the periphcral or special nerves, involvement of the heart, or any other organ, edema, etc., and sometimes death.

1 have seen the arlvance into complete helplessness of a pntient who complnined only of night-blindness with paresthesias, ancethesias and paralysis. I have seen the same paticnt, put on a cliet of whole-wheat flour, beans and peas, get perfectly well in two months. I liave taken 
into hospital patient after patient advaneing from the functional stage of symptoms into the paralyzed, and, by giving a full diet with whole-wheat bread, beans, pistatoes, macaroni and fresl meat, had them well in two weeks. I see two to three cases a day now, and during the last two months have taken in the worst ones and cured the pationts in two weeks. On one part of our coast where beriberi has been most common, in the fall of 1910 a large vessel went ashore from which wholewheat flour was unloaded to lighten her. The natives got the flour and there has not been a case there since, noj any of the functional symptoms. The "old stagers" of this country who remember the days when "brown flow" was the diet, say that this trouble was unknown nnong them. I could multiply elinical and empirical arguments endlessly, but what is the use?

Before the works of Eijkman, Frazer and Stanton, Clinmberlain and Vodder and others came out, and their significance as applied to conditions here was understood, I found this problem the harrlest to solve. Since the light thrown on this disense has been applied here, everything has been simplified. $\Lambda$ s I said in the first place, the contributing factors and the intercurrent and annlogous conditions must be recognized and allowed for, but after this the bold fact stands out that the beriberi so prevalent here is caused by the same thing here as in Asia, the use of the overmilled grain (wheat, not rice) and the exclusion of other foods.

'This must not blind us to the possibilities of other causes. The fact that peripheral neuritis is caused by alcohol does not prove that it is not caused by arsenic or diphtheria or other agents. The fact that one particular form of peripheral neurjtis, which is called beriberi, is caused by eating to the cxclusion of other foods, grain, whether rice or wheat, which has had its outer cont removed by polishing or milling, does not prove that peripheral newritis is not caused in other ways, any more than the fact that beriberi was caused by eating polished rice proved that it might not be caused hy entine overmilled whent. Here in my experience is the proof that it is, and yet the fundamental cause is no doulit tlie same.

It is no part of my purpose to follow this argument up and to advance liypotheses to explain the other causes of the disease. as, for instaner, the fact that unmilied grain may have the neuritis-preventing elements in its perjpineral layers removed, (llanged or dissolved out by dampmess, or decomposed and removed by heat, or that in certain states the body may not cause the decomposition of the proteins of other diets in the way necessary to protuce the particular substance necessary to the normal jreservation of nervous tissue. What I mainly want to do is to lend men to accept, at its worth, the work of the scientific investigntors of this problem, to apply the findings to the amelioration of whatever conditions are the cause of the discase wherever they find it, and to produce a fuller unilerstanding and recognition of the disease as a clinical entity outside of rice-enting communitics.

It looks as thougl the time were not far distant when the wanting ingredient of tile dict would be isolated and jossibly put on the market in easily handled forms, which would vastly simplify our work in the prevention nol trentment of this disease.

Mcanwhile, a dissemination of the knowledge of its symptoms. calse, plevention and cure should be taking place. There are many isolated communities in which the diet is restiveterl and in which tuberculosis is rife, to which eduation for the prevention of tuberculosis is being brought, and many of these communities are under more or less government control. It should be casy in such to include in the instructions on foods a knowlertge of the value of whole-whent flour, from the standpoint of preventing many of the prodromal, as well as severc, ills of beriberi, as well as from that of its general nutritional advantages. Where government control is possible, as in institutions, govermment relief work, etc.. whole-wheat flour should be insisted on, as has been done in the Philipp)ine Islands.

I have found the same plejudice against whole-whent flour here as has been found agninst the unpolished rice there, but it has broken down before its proved value, and, at present, I am unable to supply the demand for it locally. The old regulations devised for preventing disease on vessels should be revised to meet this new linowledge. Sailors should be made to understund the significance of some of these symptoms, and ship)-owners should understand the possibilities and means for their prevention. It should be taught that the more the diet is to be restricted to flour. the more is it necessary to liave whole-wheat flour. 'llic worse the hygienic conditions and the greater the hardships, even the more is it necessary. Or to put it in another way, whole-wheat flour is better than fine white flour for many rensons. The more one depends on it for the liet, the stronger lecome the reasons. When the staple article of diet is flour, the reasons are paramount; whole-whent flour must be used to prevent nerve-poisoning.

St. Anthony Ilonpitil.

\section{THTERAPEUTIC TI'TERATUTRE *}

EVFIR]ETT .J. J3ROWN, M.l. DECATUR, 11.L.

By "therapentic literature" I inean literature in the form of looks, monograplss, magazine articles, jourmals or tracts of optimistic and self-helpful charneter which are written in language and meaning acceptable to the laity, and which can be safely placed in the hands of certain patients to help them cure their disenses or remove their symptoms.

I know that many physicinns are already in the habit of suggesting the rending of certain books to their patients as an aid to cure, but as yet I have not been able to find where any one has systematically collated this form of literature for use in a therapentic way. It is not my purpose by any means to attempt to name all the books which are used, or might be used, but I have selected only those with which I have become acquainted, and which have proved of value to me in my professional work. These books I regard as a part of my therapentice armamentarium.

Although it is still a mooted question whether patients should be instructed in neclical matters, and I strongly olject to ever placing an orlinary merlical text-look in their hands, yet in all these books which I have selected there is nothing to suggest self-medication or to encourage introspection, and no dismnl prognoses are given, but all are encouraging and self-educative, and assist iu a logical way in producing that attitude of mind which has given the various "eulte" what suceess they have had to-day. 'These hooks teach patients to form the habit of dismissing the disagreeable, to be less self-contemplative and to look outside of themselves for life and happiness,

- Read before the Morgun County Medienl Library Assoclatlon. Jacksonvillo, II]., bel. 18, 1012. 